\title{
Impact of the isometric contraction of the calf on the local microcirculation
}

\author{
O impacto da contração isométrica da perna na microcirculação local \\ Margarida Florindo ${ }^{1,2}$, Henrique Silva ${ }^{2,3}$, L. Monteiro Rodrigues ${ }^{2,3}$ \\ ${ }^{1}$ Department of Physiotherapy, Portuguese Red Cross Superior Health School, ESCSCVP Lisboa, Portugal \\ ${ }^{2}$ CBIOS - Universidade Lusófona's Research Center for Biosciences and Health Technologies, Lisboa, Portugal \\ 3 Pharmacol. Sc Depart - Universidade de Lisboa, Faculty of Pharmacy, Lisboa, Portugal \\ Email: mflorindo@esscvp.eu
}

\begin{abstract}
The muscle pump activity is an important component of venous return. Muscle weakness in the lower limb can decrease the efficacy of the calf muscle pump and compromise adequate venous return. The aim of this study was to propose an experimental model to evaluate the impact of the calf muscular pump influence on peripheral microcirculation. We studied the local microvascular response to isometric calf contraction in the standing position. Six healthy subjects ( $31 \pm 9$ years old) participated in this study after giving informed consent. After standing for 5 minutes, subjects performed 1 minute of maintained isometric plantar flexion with both feet before resuming the original position for another 5 minutes. Local (foot) perfusion was evaluated with photoplethysmography (PPG) and laser Doppler flowmetry (LDF), pulse rate (PR) obtained from the PPG, and calf muscle activity was followed by electromyography (EMG). Nonparametric statistics were used for phase comparisons. During calf pump activity we observed significant differences of wave PPG and LDF amplitude with a rapid replacement after calf muscle contraction stopped. Pulse rate did not change during the three protocol phases. Thus, this proposed model appears suitable to further explore the role of the muscular pump activity on the peripheral microcirculation.
\end{abstract}

Keywords: muscle pump; microcirculation; lower limb; LDF; PPG.

\begin{abstract}
Resumo
A atividade da bomba muscular é um mecanismo que facilita o retorno venoso. A fraqueza muscular do membro inferior pode diminuir a eficácia da bomba muscular da perna e comprometer um adequado retorno venoso. O objetivo deste estudo foi propor um modelo experimental para avaliar o impacto da bomba muscular da perna na microcirculação. Para o efeito, estudamos a resposta microvascular periférica à atividade isométrica da bomba muscular da perna, na posição de pé. Seis indivíduos saudáveis $(31 \pm 9$ anos) participaram deste estudo após terem dado o consentimento informado. Após 5 min na posição de pé, os indivíduos realizaram 1 min de flexão plantar isométrica mantida, dos dois pés, antes de retomar a posição inicial por mais $5 \mathrm{~min}$. A perfusão da pele do pé foi avaliada com fotopletismografia (FPG) e com fluxometria por laser Doppler (FLD), a frequência de pulso (FP) foi calculada a partir da FPG e a atividade muscular da perna com eletromiografia (EMG). Foram utilizadas estatísticas não paramétricas para comparação das fases. Durante a atividade da perna, observámos diferenças significativas de onda FPG e da amplitude de FLD com uma rápida recuperação após o final da contração do músculo. A frequência de pulso não mudou durante as três fases do protocolo. Esses resultados sugerem a utilidade do modelo proposto para explorar futuramente, o impacto da atividade da bomba muscular da perna na microcirculação periférica.
\end{abstract}

Palavras-chave: bomba muscular; microcirculation; membro inferior; FLD; FPG 


\section{Introduction}

The main function of the venous circulation is to ensure the return of blood to the heart. Depending on the integrity of the veno-arterial reflex, the action of the respiratory and skeletal muscle pumps are mechanisms facilitate the pressure gradient between central and peripheral venous compartments ${ }^{[1]}$. Lifestyle may lead to a decreased physical activity, with decreased strength production ${ }^{[2]}$. The resulting weakness may lead to a decrease in lower limb blood flow and a compromise of vascular regulation mechanisms ${ }^{[3]}$. The orthostatic dynamic posture can influence vascular physiological mechanisms ${ }^{[2]}$ on a macrodynamic scale according to the specific activity of muscle groups. Several systems are activated with muscle contraction and these activations seem to correspond to important moments in the lower limbs venous pump activity. During contraction, the muscular activity produces the most effective increment of venous pressure ${ }^{[4-5]}$ and, in the lower limb, muscle pumps are located in the posterior region of the leg and thigh. Thus, the muscle contraction normally facilitates the venous return physiology, promoting the rise of blood and emptying of the venous system.

The phenomena that specifically relate muscle mechanisms (or their dysfunction) to peripheral vascular disease are not clearly defined ${ }^{[2]}$, but it is known that muscle contraction or relaxation influences venous pressure and may even alter the communication between the deep and superficial venous systems ${ }^{[6]}$.

The skin microcirculation has been used as a very practical model for the study of the peripheral circulation with the main advantage of using noninvasive techniques ${ }^{[7-8]}$. In a healthy limb, the contraction of the muscles located in the posterior region of the leg, such as the gastrocnemius and the soleus, allow changes in the local venous volume ${ }^{[9]}$. The angles' variability influence segments and joints ${ }^{[10-13]}$ and are related with the exchange energy performed during the movement. [4,9,13-15]

\section{Material and Methods}

Six healthy subjects (age $-31 \pm 9$ years old, weight $61.8 \pm 14.3 \mathrm{~kg}$, height $-1.65 \pm 0.5 \mathrm{~m}$ ), both sexes (three females and three males), nonsmokers, participated in this study after informed written consent. None reported any previous or current history of cardiovascular disease, or use of vasoactive medication. All procedures fully complied with the principles of the Helsinki Dec-

\section{Introdução}

A principal função da circulação venosa é assegurar o retorno do sangue ao coração. Dependendo da integridade do reflexo veno-arterial, a ação das bombas musculoesqueléticas e respiratórias, são mecanismos que facilitam o gradiente de pressão, entre os compartimentos venosos centrais e periféricos ${ }^{[1]}$. $\mathrm{O}$ estilo de vida pode levar a uma diminuição da atividade física, manifestada pela diminuição da produção de força ${ }^{[2]}$. A fraqueza resultante pode levar a uma diminuição no fluxo sanguíneo dos membros inferiores e a um comprometimento dos mecanismos de regulação vascular ${ }^{[3]}$. A postura ortostática dinâmica pode influenciar mecanismos fisiológicos vasculares ${ }^{[2]}$ em escala macrodinâmica de acordo com a atividade específica dos grupos musculares. Vários sistemas são ativados com contração muscular e parecem corresponder a momentos importantes na atividade da bomba venosa dos membros inferiores. A atividade muscular produz, durante a contração, o aumento mais efetivo da pressão venosa ${ }^{[4-5]} \mathrm{e}$, no membro inferior, as bombas musculares estão localizadas na região posterior da perna e coxa. Assim, a contração muscular normalmente facilita a fisiologia do retorno venoso, promovendo o aumento do sangue e esvaziando o sistema venoso.

Os fenômenos que relacionam especificamente os mecanismos musculares (ou a sua disfunção) com a doença vascular periférica não estão claramente definidos ${ }^{[2]}$, mas é sabido que, com a contração ou relaxamento muscular, há variações na pressão venosa que alteram a comunicação entre o sistema venoso profundo e o superficial ${ }^{[6]}$.

A microcirculação da pele tem sido utilizada como um modelo prático para o estudo da circulação periférica com a principal vantagem de usar técnicas não invasivas ${ }^{[7-8]}$. Num membro saudável, a contração dos músculos localizados na região posterior da perna, como o gastrocnémio e o solhar, permitem alterar o volume venoso $\left.{ }^{[9}\right]$. A variabilidade dos ângulos influencia segmentos e articulações ${ }^{[10-13]}$ e está relacionada com trocas de energéticas durante o movimento ${ }^{[4,9,13-15]}$.

\section{Materiais e Métodos}

Seis indivíduos saudáveis (idade - $31 \pm 9$ anos, peso - $61,8 \pm 14,3 \mathrm{~kg}$, altura $-1,65 \pm 0,5 \mathrm{~m}$ ), de ambos os sexos (três mulheres e três homens), não fumadores, participaram deste estudo após terem dado conhecimento informado por escrito. Os voluntários não apresentavam história anterior ou atual de doença cardiovascular, nem estavam sujeitos a qualquer medicação vasoativa. 
laration and following amendments ${ }^{[16]}$. Measurements were taken in a room with controlled temperature $(25 \pm$ $1{ }^{\circ} \mathrm{C}$ ) and humidity $(40-60 \%)$ conditions. After stabilizing for at least 10 minutes sitting up straight, the subjects performed the protocol in the standing position as follows - standing for 5 minutes with both feet parallel to each other and hands placed on a table for postural support (Phase I), 1 minute of maintained active isometric plantar flexion of both feet with minimum oscillation (Phase II), and the return to the initial position for a further 5 minutes to recovery while standing (Phase III), as shown in Figure 1. The plantar flexion range, demanding a comfortable contraction, was measured with a goniometer (Goniometer Angle Medical Ruler Rule Joint Bend Measure Plastic PVC 8" 200mm, Enrad-nonius). A reflection photoplethysmography (PPG) sensor was used (Blood Volume Pulse sensor, PLUX Biosignals, Portugal) and placed along the medial longitudinal arch of both feet, approximately $2 \mathrm{~cm}$ distally to the first metatarsal phalange joint and held with a double-sided adhesive strip to minimize the occurrence of probe-tissue movement artefacts. The influence of the ambient light on the PPG recording was also minimized by covering the sensor with an opaque adhesive tape. Additionally, two laser Doppler flowmetry (LDF) probes (457 small angled probe, Perimed, Stockholm) were also used, placed $1 \mathrm{~cm}$ proximally from the PPG probe (in the medial longitudinal arch) and fixed with a double-side adhesive tape. Finally, the electrical activity of both gastrocnemii was evaluated by electromyography (EMG, PLUX Biosignals, Portugal). Both PPG sensor and EMG electrodes were attached to a microprocessor board (BITalino Plugged board, PLUX Biosignals, Portugal).
Todos os procedimentos respeitaram plenamente os princípios da Declaração de Helsinky ${ }^{[15]}$.Os procedimentos foram realizados numa sala com temperatura controlada $\left(25 \pm 1^{\circ} \mathrm{C}\right)$ e condições de umidade (40$60 \%$ ). Depois de um período de estabilização durante pelo menos 10 minutos sentados, os sujeitos realizaram o protocolo na posição de pé da seguinte forma - Posição de pé durante 5 minutos com os dois pés paralelos e as mãos apoiadas numa mesa para suporte postural (fase I), 1 min de flexão plantar isométrica ativa mantida de ambos os pés com oscilação mínima (fase II) e o retorno à posição inicial de pé por mais 5 minutos para recuperação (fase III), como ilustrado na Figura 1. Foi pedida a realização de uma flexão plantar confortável e a amplitude medida com um goniómetro (Goniometer Angle Medical Ruler Rule Joint Bend Measure Plastic PVC 8" 200mm, Enrad-nonius). Foi utilizado um sensor de reflexão de fotopletismografia (FPG) (sensor de Pulso de Volume Sanguíneo, PLUX Biosignals, Portugal) e colocado ao longo do arco longitudinal interno de ambos os pés, aproximadamente $2 \mathrm{~cm}$ distalmente da primeira articulação metatarso falângica e mantido com uma tira adesiva de face dupla, para minimizar a ocorrência de artefactos de movimento de sonda-tecido. A influência da luz ambiente na gravação FPG também foi minimizada cobrindo o sensor com uma fita adesiva opaca. Foram utilizadas duas sondas FLD (457 pequenas sondas angulares, Perimed, Estocolmo), colocadas a $1 \mathrm{~cm}$ no sentido proximal da sonda FPG (no arco longitudinal interno) e fixas com uma fita adesiva de face dupla. Finalmente, a atividade elétrica de ambos os gastrocnémios foi avaliada por eletromiografia (EMG, PLUX Biosignals, Portugal). Tanto o sensor FPG como os elétrodos EMG foram anexados a uma placa de microprocessador (placa BITalino Plugged, PLUX Biosignals, Portugal).
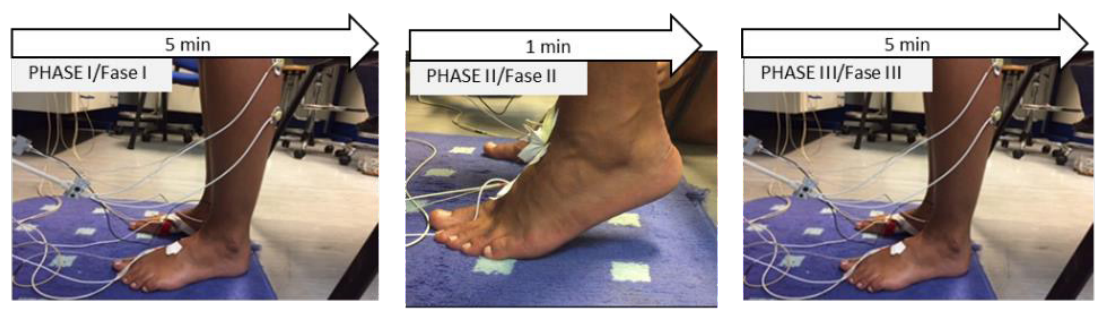

Figure 1/ Figura 1 - Phase I (standing position - 5 min); Phase II (active plantar flexion - $1 \mathrm{~min}$ ); Phase III (recovery standing - 5min)

Fase I (posição de pé estática - 5min); Fase II (flexão plantar ativa-1 min); Fase III (recuperação na posição de pé -5 min) 
Skin blood flow was calculated as the mean waveform amplitude for the PPG signals, and as the mean amplitude of the LDF signals, both expressed in arbitrary units (AU). Pulse Rate (PR) was calculated as the number of PPG waveforms per minute $(/ \mathrm{min})$. Blood flow and PR were calculated for each minute of the protocol and were averaged to give the corresponding value for each phase. The muscle electrical activity was expressed as the ratio of the root mean square (rms) of each phase relative to Phase I. In each phase, the rms was calculated on the signal segments with $500 \mathrm{~ms}$ of duration that presented the highest amplitude.

For all signals, results are expressed as the calculated mean values for both feet. The Wilcoxon signed-rank test was used for phase comparisons, and a $\mathrm{p}$ value $<0.05$ adopted.

\section{Results and Discussion}

This study aims to design an experimental methodology to evaluate the impact of the muscular pump activity on microcirculation, a most relevant issue to better understand the normal movement physiology, but also to understand the potential consequences of a weaken muscle activity in microcirculation, and the influence of vascular deficit on muscle recruitment and movement. These are surely relevant determinants of movement rehabilitation.

We used EMG, which provides an estimation of the muscular activation by recording potentials from electrodes placed near the muscle, and two different non-invasive techniques to follow the local perfusion changes during muscle activity. The time evolution of the recorded variables is shown in Figure 2, and the means of the calculated parameters is presented in Table 1.

During the isometric contraction (Phase II), the gastrocnemius electrical activity increased significantly $(\mathrm{p}=0.043)$, as expected. The median flexion range was $20.5^{\circ}$, which corresponds to the mean of the angle obtained during the propulsion gait phase ${ }^{[13-15]}$. PR did not change significantly throughout the protocol.

As for the vascular signals, different responses were observed. While the LDF signal showed a significant increase ( $p=0.027)$, PPG showed a significant decrease $(p=0.028)$. Although at a first glance, these results seem to be contradictory, this has been reported in previous studies ${ }^{[17-18]}$ and are likely related to the differences in the measurement depth of these techniques. PPG is a technique that registers changes in blood volume synchronous with cardiac activity. Because the venous vascular component partly contributes to its signal, PPG
O fluxo sanguíneo da pele foi calculado como a amplitude média de onda para os sinais FPG, e como a amplitude média dos sinais FLD, ambos expressos em unidades arbitrárias (AU). A frequência de pulso (FP) foi calculada como o número de ondas FPG por minuto (/ min). O fluxo sanguíneo e FP foram calculados para cada minuto do protocolo, seguido do cálculo da média para chegar ao valor correspondente para cada fase. A atividade elétrica muscular foi expressa como a proporção do quadrado médio de raiz (rms) de cada fase, em relação à fase I. Em cada fase, o rms foi calculado nos segmentos de sinal com $500 \mathrm{~ms}$ de duração, que apresentaram maior amplitude.

Para todos os sinais, os resultados são a média dos valores calculados para ambos os pés. O teste de classificação de Wilcoxon foi utilizado para comparações de fase e foi adotado o valor $\mathrm{p}<0,05$.

\section{Resultados e Discussão}

Este estudo tem como objetivo projetar uma metodologia experimental para avaliar o impacto da atividade da bomba muscular na microcirculação, o que é uma foco relevante para entender melhor a fisiologia do movimento normal, para entender as possíveis consequências da fraqueza muscular na microcirculação e também qual a influência do défice vascular no recrutamento muscular e no movimento. Estes são determinantes de relevo na reabilitação de movimentos.

Utilizamos o EMG que permite uma estimativa da ativação muscular por potenciais de gravação a partir de elétrodos colocados perto do músculo e duas técnicas não-invasivas diferentes para acompanhar as mudanças locais de perfusão durante a atividade muscular. A evolução no tempo das variáveis gravadas está apresentada na Figura 2, e as variáveis médias dos parâmetros calculados estão presentes na Tabela 1.

Durante a contração isométrica (fase II), a atividade elétrica dos gastrocnémios aumentou significativamente $(\mathrm{p}=0,043)$, conforme esperado. A média da amplitude da flexão foi de $20,5^{\circ}$, o que corresponde à média do ângulo realizado durante a fase de marcha da propulsão ${ }^{[13-15]}$. A FP não mudou significativamente ao longo do protocolo.

Quanto aos sinais vasculares, observaram-se diferentes respostas. Enquanto o sinal FLD mostrou um aumento significativo ( $p=0,027)$, o FPG mostrou uma diminuição significativa $(\mathrm{p}=0,028)$. Embora, à primeira vista, esses resultados parecem contradizer os publicados anteriormente ${ }^{[17-18]}$, eles podem ser explicados devido às diferenças nas profundidades de medição destas técnicas. 

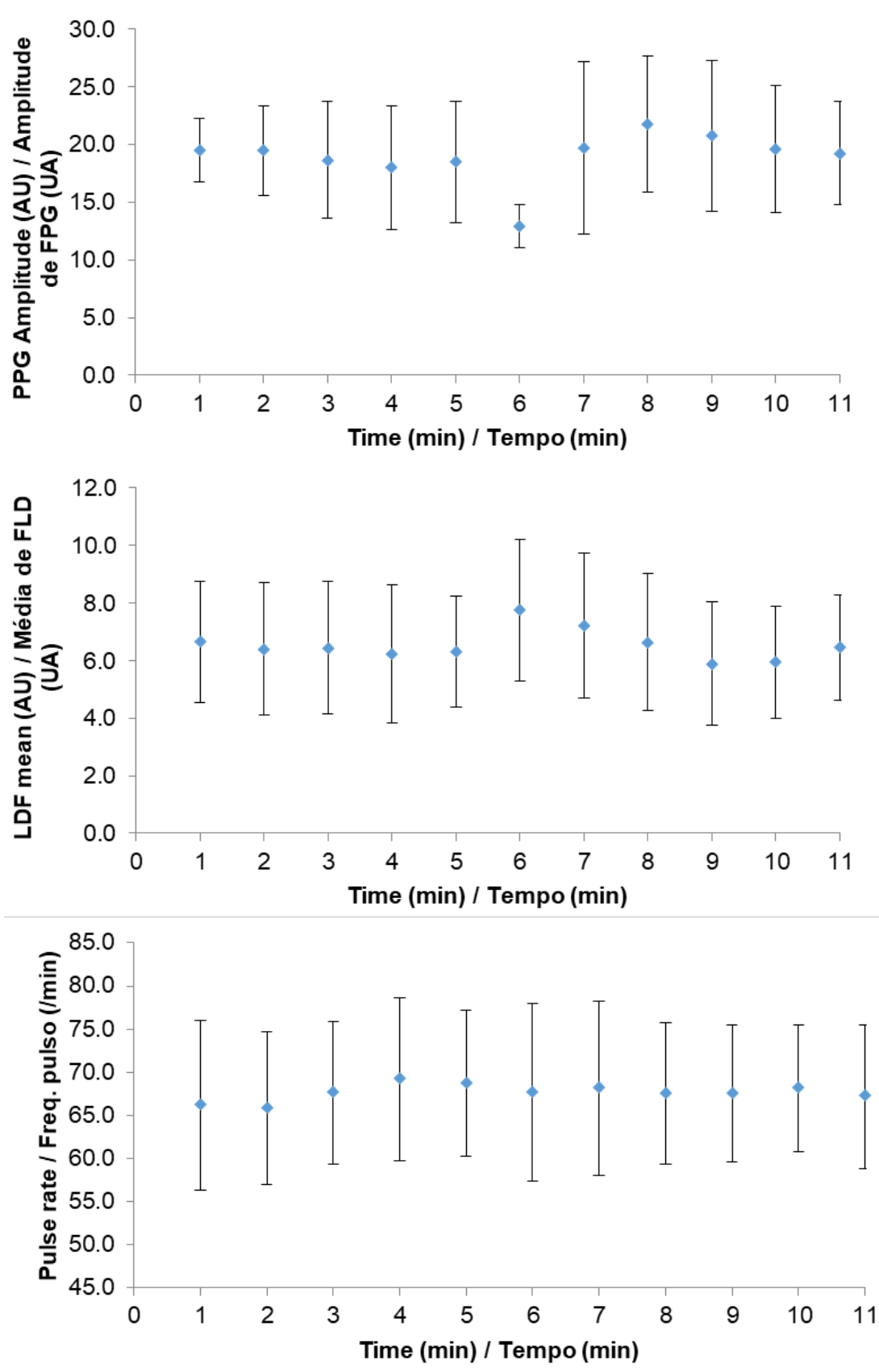

Figure 2/ Figura 2 - Time evolution of the mean PPG (A), LDF (B) and PR $(C)$ signals throughout the protocol.

Evolução temporal dos sinais médios de FPG (A), FLD (B) e FP (C) ao longo do protocolo. 
Table 1/Tabela 1 - Mean and standard deviations of the calculated parameters for the three phases of the protocol. Statistial comparison for Phase I $(*-p<0.05)$ Média e desvio-padrão dos parâmetros calculados para as três fases do protocolo. Comparação estatísrica com a fase I $(*-p<0,05)$

\begin{tabular}{|c|c|c|c|c|}
\hline & & Phase I / Fase I & Phase II / Fase II & Phase III / Fase III \\
\hline \multirow{3}{*}{$\begin{array}{c}\text { PPG (AU) / FPG } \\
\text { (UA) }\end{array}$} & mean & 18.8 & 12.9 & 20.2 \\
\hline & SD & 2.4 & 1.7 & 3.0 \\
\hline & p-value & - & $0.028^{*}$ & 0.138 \\
\hline \multirow{3}{*}{ LDF / FLD (UA) } & mean & 6.4 & 7.8 & 6.4 \\
\hline & SD & 2.1 & 2.3 & 2.0 \\
\hline & p-value & - & $0.027 *$ & 0.893 \\
\hline \multirow{3}{*}{$\begin{array}{c}\text { Pulse rate / } \\
\text { Frequência de pulso } \\
\text { (/min) }\end{array}$} & mean & 67.5 & 67.7 & 67.7 \\
\hline & SD & 8.8 & 10.3 & 8.0 \\
\hline & p value & - & 0.753 & 0.715 \\
\hline \multirow{3}{*}{ EMG rms ratio } & mean & 1.00 & 1.44 & 0.94 \\
\hline & SD & 0.00 & 0.48 & 0.16 \\
\hline & $\mathrm{p}$-value & - & $0.043 *$ & 0.593 \\
\hline
\end{tabular}

allows the evaluation of the efficiency of the muscular pump ${ }^{[20-21]}$. The PPG potential for the evaluation of vascular disease has been recognized for decades ${ }^{[18]}$ and it is currently used in venous hemodynamic studies, allowing venous refill evaluation and venous reflux quantification parameters ${ }^{[1,16,22-23]}$. In turn, LDF has gained relevance as a sophisticated instrument to assess the blood flow in small tissue volumes, particularly in skin areas of low capillary density ${ }^{[24-31]}$. In any case, however, none of these systems provide numbers expressed in absolute values, which means that a direct correspondence with the physiological variables cannot be drawn. Under these circumstances, to be sure of its validity, it is critical to confirm the coherence of data in terms of its reproducibility and to compare it with other hemodynamical data.

No differences were detected between baseline and recovery, meaning an immediate adaptation capacity following the amplitude variations initiated by the muscular contraction ${ }^{[32]}$, restoring the inflow necessary to maintain the static standing position. It is generally accepted that vascular diameter is also controlled by the metabolic demands of the muscles ${ }^{[3-34]}$, by the autonomic regulation of the blood flow. But other media-
Como o componente vascular venoso contribui parcialmente para o sinal de PPG, este permite a avaliação da eficiência da bomba muscular ${ }^{[20-21]}$. O potencial de PPG para a avaliação da doença vascular tem sido reconhecido por décadas ${ }^{[18]} \mathrm{e}$ atualmente é usado em estudos hemodinâmicos venosos, permitindo a avaliação da recarga venosa e parâmetros de quantificação do refluxo venoso ${ }^{[1,16,22-23]}$. Por sua vez, o LDF ganhou relevância como um instrumento sofisticado para avaliar o fluxo sanguíneo em pequenos volumes de tecido, particularmente em áreas de pele de baixa densidade capilar [24-31]. Mas, em qualquer caso, nenhum desses sistemas fornece números expressos em valores absolutos, o que significa que não é possível desenhar uma correspondência direta com as variáveis fisiológicas. Nessas circunstâncias, para ter certeza de sua validade, é fundamental confirmar a coerência dos dados em termos de sua reprodutibilidade e compará-lo com outros dados hemodinâmicos.

Não foram identificadas diferenças entre a linha de base e a recuperação, o que significa uma capacidade de adaptação imediata após as variações de amplitude iniciadas pela contração muscular ${ }^{[32]}$, restaurando a entrada de sangue necessária para manter uma posição es- 
tors (acetylcholine, from the motor plaque, endothelial NO) might be present ${ }^{[33-34]}$ and contribute to the local response that still needs to be further explored.

\section{Conclusion}

The proposed methodology seems to provide conditions to further explore, in vivo, the impact of the calf muscle pump activity on microcirculation.

\section{Acknowledgements}

The authors would like to express their thanks to all the volunteers for their participation in this study.

\section{Conflict of interests}

The authors declare that there are no financial and/or personal relationships that could be viewed as presenting a potential conflict of interests. tática de pé, estável. É geralmente aceite que o diâmetro vascular também é controlado pelas exigências metabólicas dos músculos ${ }^{[33-34]}$ e pela regulação autonómica do fluxo sanguíneo. Mas outros mediadores (acetilcolina, da placa motora, NO endotelial) podem estar presentes [33-34] e contribuem para a resposta local, o que ainda necessita de ser identificada em estudos futuros.

\section{Conclusão}

A metodologia proposta parece apresentar condições para explorar no futuro, in vivo, o impacto da atividade da bomba muscular da perna na microcirculação.

\section{Agradecimentos}

Os autores gostariam de expressar os seus agradecimentos a todos os voluntários que participaram neste estudo.

\section{Conflito de interesses}

Os autores declaram que não há relações financeiras e/ ou pessoais, que possam ser entendidas como apresentando um potencial conflito de interesses. 


\section{References/ Referências}

1. Meissner MH, Moneta G, Burnand K, Gloviczki P, Lohr JM, Lurie F, et al. The hemodynamics and diagnosis of venous disease. Journal of vascular surgery. 2007 Dec;46 Suppl S:4S-24S.

2. Stoller M, Stoller D, Seiler C. Physical exercise and quantitative lower limb collateral function. Open heart. 2016. 3(1):e000355.

3. Tanno J, Gatate Y, Kasai T, Nakano S, Senbonmatsu T, Sato O, et al. A Novel Index Using Ankle Hemodynamic Parameters to Assess the Severity of Peripheral Arterial Disease: A Pilot Study. PLoS ONE, 2016. 11(10): e0164756. doi:10.1371/journal.pone.0164756

4. Recek C. Calf pump activity influencing venous hemodynamics in the lower extremity. Int J Angiol. 2013 Mar; 22(1):23-30.

5. Stranden E. Venodynamics in healthy subjects and in patients with venous dysfunction. 1998. https://www.researchgate.net/publication/228481929

6. Na P, Kim L, Lee M. Effects of gait training with horizontal impeding force on gait and balance of stroke patients. Journal of physical therapy science. 2015 Mar;27(3):733-6.

7. Santello M, Lang CE. Are movement disorders and sensorimotor injuries pathologic synergies? When normal multi-joint movement synergies become pathologic. Frontiers in human neuroscience. 2015 8:1050.

8. Silva H, Ferreira H, Bujan J, Monteiro Rodrigues L. Exploring the oxygen challenge test as a microcirculation evaluation model. Biomed Biopharm Res. 2013; (10) 2: 209-215.

9. Jacob M, Chappell D, Becker BF. Regulation of blood flow and volume exchange across the microcirculation. Critical care (London, England). 2016 Oct 21; 20(1):319.

10. Ivanenko YP, Poppele RE, Lacquaniti F. Five basic muscle activation patterns account for muscle activity during human locomotion. The Journal of physiology. 2004 Apr 01; 556(Pt 1):267-82.

11. Donath L, Faude O, Lichtenstein E, Nuesch C, Mundermann A. Validity and reliability of a portable gait analysis system for measuring spatiotemporal gait characteristics: comparison to an instrumented treadmill. Journal of Neuroengineering and Rehabilitation. 2016 Jan 20; 13:6.

12. Ferrari A, Ginis P, Hardegger M, Casamassima F, Rocchi L, Chiari L. A Mobile Kalman-Filter Based Solution for the Real-Time Estimation of SpatioTemporal Gait Parameters. IEEE Trans Neural Syst Rehabil Eng. 2016 Jul; 24(7):764-73.

13. Hamacher D, Hamacher D, Müller R, Schega L, Zech A. Exploring phase dependent functional gait variability. Human Movement Science 52 (2017) 191-196

14. Neptune RR, Clark DJ, Kautz SA. Modular control of human walking: a simulation study. Journal of biomechanics. 2009 Jun 19; 42(9):1282-7.

15. Seethapathi N, Srinivasan M. The metabolic cost of changing walking speeds is significant, implies lower optimal speeds for shorter distances, and increases daily energy estimates. Biology letters. 2015 Sep; 11(9):20150486.

16. World Medical Association Declaration of Helsinki Ethical Principles for Medical Research Involving Human Subjects. JAMA. 2013;310(20):21912194

17. Silva H, Rocha C, Rodrigues LM. Combining laser-Doppler flowmetry and photoplethysmography to explore in vivo vascular physiology. Biomed Biopharm Res 2016; (13)2:209-217.

18. Rocha C, Silva H, Ferreira H, Rodrigues LM. About the in vivo discriminatory capacity of photoplethysmography versus laser Doppler flowmetry. Biomed Biopharm Res 2017; (14)1:37-44

19. Jarchi D, Casson A. Description of a Database Containing Wrist PPG Signals Recorded during Physical Exercise with Both Accelerometer and Gyroscope Measures of Motion. 2017. Data, 2, 1; doi: 10.3390/data2010001.

20. Allen J. Photoplethysmogrphy and it application in clinical physiological measurement. Physiological Measurement. Mar; 28(3):R1-39. Epub 2007 Feb 20.

21. Van Bemmelen P, Bedford G, Phi K, and Strandness D, Wash S. Quantitative segmental evaluation of venous valvular reflux with duplex ultrasound scanning. October 1989. Volume 10, Number 4

22. Fronek A, Vanderweijer I. Noninvasive determination of venomuscular efficiency. Journal of Vascular Surgery. 2003. Volume 37, Number 4

23. Kubasch ML, Kubasch AS, Torres Pacheco J, Buchmann SJ, Illigens BM, Barlinn K and Siepmann T. Laser Doppler Assessment of Vasomotor Axon Reflex Responsiveness to Evaluate Neurovascular Function. 2017. Front. Neurol. 8:370. doi: 10.3389/fneur.2017.00370

24. Tran BD, Chiu A, Tran C, Rogacion D, Tfaye N, Ganesan G, Galassetti P. Exercise and Repeated Testing Improves Accuracy of Laser Doppler Assessment of Microvascular Function Following Shortened (1-min) Blood Flow Occlusion. Microcirculation. 2016 May; 23(4): 293-300. doi:10.1111/ micc. 12277 .

25. PriesA,SecombT. Modelingstructuraladaptationofmicrocirculation. Microcirculation.2008November; 15(8):753-764.doi:10.1080/10739680802229076

26. Garg A, Xu D, Blaber A. Statistical validation of wavelet transform coherence method to assess the transfer of calf muscle activation to blood pressure during quiet standing. BioMedical Engineering OnLine 2013, 12:132. http://www.biomedical-engineering-online.com/content/12/1/132

27. Verma A, Garg A, Xu D, Bruner M, Fazel-Rezai R, Blaber A, Tavakolian K. Skeletal Muscle Pump Drives Control of Cardiovascular and Postural Systems. 2017. Scientific Reports | 7:45301 | DOI: 10.1038/srep45301 1

28. Husmann M, Willenberg T, Keo H, Spring S, Kalodiki E, Delis K. Integrity of venoarteriolar reflex determines level of microvascular skin flow enhancement with intermittent pneumatic compression. Journal of Vascular Surgery. 2008. Volume 48, Number 6.

29. Delp MD, O'Leary D. Integrative control of the skeletal muscle microcirculation in the maintenance of arterial pressure during exercise J Appl Physiol 97: 1112-1118, 2004;10.1152/japplphysiol.00147.2003.

30. Jurczak I, Jurczak K, Irzmański R. The Effects of Controlled Physical Training on Peripheral Circulation Following Interventional Treatment of Coronary Artery Disease. Adv Clin Exp Med 2016, 25, 5, 851-859. Doi: 10.17219/acem/36358

31. PriesA,SecombT. Modelingstructuraladaptationofmicrocirculation. Microcirculation.2008,November; 15 (8): 753-764doi:10.1080/10739680802229076

32. Hartwich D, Dear W, Waterfall J, Fisher J. Effect of muscle metaboreflex activation on spontaneous cardiac baroreflex sensitivity during exercise in humans. J Physiol 589.24 (2011) pp 6157-6171

33. Schinzari F, Iantorno M, Campia U, Mores N, Rovella V, Tesauro M, Di Daniele N, Cardillo C. Vasodilator responses and endothelin-dependent vasoconstriction in metabolically healthy obesity and the metabolic syndrome. Am J Physiol Endocrinol Metab. 2015 Nov 1; 309(9): E787-E792.

34. Richardson JK, Thies SB, DeMott TK, Ashton-Miller JA. A comparison of gait characteristics between older women with and without peripheral neuropathy in standard and challenging environments. Journal of the American Geriatrics Society. 2004 Sep; 52(9):1532-7. 